\title{
Hans-Helmuth Gander
}

\section{Selvværen og historie Gadamers konception af virkningshistorie og virkningshistorisk bevidsthed}

I.

Det kan stå som indgangstese for de følgende overvejelser, at historien fremtræder i enhver omsiggribende dimension, hvori den menneskelige selvunderretning sætter sig i værk. Dermed er det for det første sagt, at menneskets væren selv er historisk. Og dermed påpeges det samtidig, at der på fundamentet af og $i$ horisonten af dets historiske væren åbner sig en mulighed for mennesket $\mathrm{i}$ den eksplicitte eftertanke over historien for at forvisse sig om sig selv, som ligefrem er identitetsstiftende, idet historien altså er et "medium for identitetsdannelsen". ${ }^{1}$ Denne identitetsdannende funktion, der tilskrives historien, refererer dermed til den individuelle såvel som den sociale livsverden og viser således hen til de konstitutive træk, som indfletter den historiske virkelighed i den menneskelige selvværen. Denne selvværen, som i den forstående venden sig mod historien søger at komme til en forståelse af sine muligheder, afsøger dermed sin egen fakticitet såvel som individualitet "som en forståelse af den egne handlens og villens retning og grænser, [samt] som grundlag for en væren-et-med-sig-selv (mit-sich-Einswerden) i sin fulde blevethed (Gewordensein) [og] som fastholdelse af det, der har været, og modstand mod forsvinden. ${ }^{2}$

Refleksionen over historien betyder derfor så også, at den eftertænksomme altid allerede selv er involveret $i$ historien. Ingen indleder historien og ingen begynder den, hvorfor man heller aldrig kan reflektere neutralt eller ab ovo over historien. Inddraget i historien er mennesket gennem sin biografi, der altid gestalter sig $\mathrm{i}$ de historiske begivenheders og udviklingers magtsfære. Omvendt spejler disse sig i biografien, er således indskrevet i den, at de så at sige graverer livet og først gennem denne gravering producerer biografiens individuelle profil. Af samme grund lader biografien sig aldrig løse fra erfarin- 
gen af den virkelighed, der altid allerede er historie for menneskene. Anskuet på denne måde er historien det medium, hvorigennem vi må sætte vort liv i værk. Følgelig har det menneskelige liv ikke karakter af en substans, som biografien i sit faktiske forløb og sine historiske detaljer kan koble sig på som en væsenskerne. Og derfor viser livshistorien sig altså heller ikke at være en besiddelse, der står til rådighed for et autonomt subjekt. Med en variation over en velkendt gadamersk formulering kan man med Georg Picht sige: "i virkeligheden har vi ikke vores biografi, men vores biografi har os. [Det vil sige:] Vi bliver produceret af vores biografi; man kunne også sige: vi er ikke andet end vores biografi." "3ed den deri indlejrede fortrolige genealogi er de historiske indvirkninger og begivenheder også allerede inkluderet i biografien, der lader den enkelte blive til det, han er. Omvendt har også den såkaldte "verdenshistoriens gang" sin eneste fremtrædelsesform i det konkrete levnedsløb, således at $i$ denne konstitutive gensidighed mellem eksistens og verdenshistorien lader den ene sig ikke tænke uden den anden, ligesom de altid kun kan profilere sig igennem denne vekselvirkning.

Repræsenterer vor biografi på denne vis historien, så kan man med udgangspunkt i Picht opstille den tese, at "meningerne om historien bestemmer vort forhold til os selv" gelfuldt eller misforstår den, så misforstår vi nødvendigvis også os selv. Deraf følger, at spørgsmålet om historisk forståelse er af fundamental betydning for de begreber om selvunderretning, som har gestaltet sig i menneskets eksistentielt-aprioriske forholden sig til sig selv. Ud fra disse præmisser kan historien altså ikke reduceres til den objektive bestemmelse af summen af historisk datérbare begivenheder, der gang på gang har forledt til i analogi til naturen at objektivere historien $\mathrm{i}$ dens givethed, om end nok som proces, så dog stadig efter dens materielle indhold. I modsætning dertil findes historien faktisk kun i og med, at den anskueliggøres. Det vil sige, at historien i strengeste forstand kun findes, for så vidt og så længe, at der findes en korrelativ bevidsthed om den. I egentlig forstand kan der altså kun tales om historie, når de faktiske hændelser i en ontologisk transposition overleverer sig som fortsat tale igennem erindringen.

Binder historien sig i denne forstand til sin anskueliggørelse, findes historien altså ikke uden historiebevidsthed, hvorfor en historierefleksion, der udfolder sig under hermeneutiske forudsætninger, fra første færd må undgå enhver form for hypostatisering, der som f.eks. hos Augustin i historieteologisk forstand eskatologisk fortegner det historiske forløb betragtet som udvikling til en frelseshistorie. I refleksionen må man endvidere afvise enhver hypostase, der som historiefilosofi i forlængelse af oplysningen - her forstået i Voltaires videre betydning af ordet $-\mathrm{i}$ overensstemmelse med den moderne ophøjelse 
af fornuftssubjektet, som bekendt, forankrer menneskehedens historie i en fremskridtsoptimisme, som ledsages af kravet om en systematisk og forklarlig mening med historien, sådan som det er kendetegnende for Hegels og Marx' monumentale modeller.

$\mathrm{Nu}$ driver den idealistiske systemtænknings såkaldte sammenbrud i midten af det forrige århundrede som bekendt historiefilosofien ud i en krise og initierer dermed en tænkning, som senere forbinder den filosofiske tematisering af det historiske med en afgørende skepsis over for monistiske historieopfattelser, som med deres krav om systematiserbarhed påberåber sig beviset på en indre lovmæssighed i historien. Navne som bl.a. J. G. Droysen, J. Burckhardt, W. Dilthey eller også F. Nietzsche repræsenterer denne kritik af de idealistiske historiespekulationer og deres rationalistiske selvoverbebyrdelse. ${ }^{5}$ Hvad der derpå fremkommer som resultat af denne kritik af enhed, nødvendighed og påstået helhedsmening er et lige så polycentrisk som multivalent teorilandskab, der bevirker en historisering af tænkningen og som i stedet for en universalhistorie for menneskeheden har den historiske kultur i dens irreducibel mangfoldighed som tema.

Pluralitet og perspektivisme er de strukturelle kendetegn, som den historieforståelse, der nu danner sig, figurerer under. Spektret af tilgange var således i sig selv broget og overordentligt vidtfavnende. Der findes imidlertid en problemstilling, der er velegnet til, som en Ariadnetråd, at vise vej gennem mangfoldighedens labyrint, og til samtidig at bane vejen for, at hermeneutikken kunne få afklaret sit eget forhold til historien, i hvilken forbindelse det dog skal nævnes, at der lige så lidt findes én hermeneutik som der findes én filosofi. Hvad der sigtes til, er den refleksive anstrengelse, som analyserer betingelserne for historisk erkendelse med henblik på en teori om historisk viden, der indtræder som erkendelses- såvel som videnskabsteoretisk metodologi for historievidenskaben. I særdeleshed Droysens "Historik" kommer med banebrydende bidrag, og i Diltheys tænkning kulminerer anstrengelserne, idet de ud fra intentionen om en 'kritik af den historiske fornuft' som bekendt går bagom erkendelsen tilbage til livet. Netop deri frilægges historien imidlertid som medium for selvkonstitutionen. Den historiske forståelses subjekt er i sig selv ikke blot et "villende, følende, forestillende væsen", men samtidig også historisk subjekt, der allerede eksisterer historisk, således at dét at erkendelsessubjektet er indeholdt på objektplanet fremstår som metodologisk nøgle for den historiske forståelse, hvorfor Dilthey som bekendt fremhæver 'sammenhængen mellem liv, udtryk og forståelse' som det endeligt konstituerende. Det vil sige, at den historisk-samfundsmæssige verden bliver åndsvidenskabernes emne, "for så vidt", betoner Dilthey, "at de formår at komme til udtryk i livsytringer, og for så vidt disse udtryk bliver forstået". 6 
Ud fra dette perspektiv bliver det historiske selv integreret i den omfattende livssammenhæng, som den historisk forstående tilhører, således at historien altså ikke blot tager sig ud som et begunstiget objektrige, men derimod fremstår som et selvåbenbarende medium for mennesket, og hvad angår forholdet mellem historie og selvværen afdækker en gensidighed. "Hvad mennesket er, fortæller alene hans historie ham", 7 hedder det i et taleudkast af Dilthey, og det betyder netop også, at i henhold til den af Dilthey intenderede metafysikkritik findes der ikke noget menneskeligt væsen, som går forud for at være livets objektiveringer, eller nogen ahistorisk, transcendentalt formuleret og selvberoende sandhed, men derimod kun menneskets selverkendelse, der altid henviser til historien.

Denne gensidighed, der allerede i en deskriptiv hensigt er blevet omtalt som sammenhængen mellem biografi og historie, er konstitutivt bestemmende for den hermeneutiske tilgang til historien, hvis forståelse i forlængelse af Heidegger $i$ en slags ontologisk vending blev udpeget som et grundlæggende eksistentiale for den menneskelige væren-i-verden. Det var et skridt igennem den dør, på hvis tærskel Dilthey på grund af sine erkendelsesteoretiske forudsætninger endnu sad. ${ }^{8}$ I Heideggers følge er det som bekendt blevet Hans-Georg Gadamers hermeneutik, som mest udførligt har udarbejdet vekselforholdet mellem historie og selvværen, og det i opposition til de subjekteoretiske positioner, der refleksionsfilosofisk så at sige absorberer historien i selvforholdet. Heroverfor vil Gadamer tydeliggøre, at og hvordan "refleksionens almagt" begrænser sig der, hvor en virkelighed bliver fremstillet som historiens forudgående virkning i den menneskelige væren. Modbegrebet til refleksionen bliver da den hermeneutiske erfaring. Den deri indlejrede tankesammenhæng mellem selvværen og historie, som Gadamer udvikler den i "Sandhed og Metode" gennem begrebet virkningshistorie, skal det derfor handle om i de efterfølgende udredninger.

\section{II.}

For Gadamer må en "sagsrelateret hermeneutik [...] påvise historiens virkelighed i forstålsen selv" (305/233). Det, der her kræves, kalder Gadamer for virkningshistorie, hvad tillige betyder: "forståelsen er essentielt en virkningshistorisk proces" (305/233). Virkningshistorien regnes med rette for "kernen i den gadamerske hermeneutik". ${ }^{10}$ I overensstemmelse med denne status fungerer den som det princip, hvorom det med Jean Grondin og en vis tilspidsning lader sig sige, at ud fra det "kan man næsten deducere hele hans hermeneutik". ${ }^{11}$ I en formulering, der nærmer sig et paradoks, kunne man sige, at Gadamers princip om virkningshistorie er en filosofi om historie uden 
en historiefilosofi. ${ }^{12}$

I gadamersk forstand betyder virkningshistorie ethvert forhold mellem fortid og nutid, hvori fortiden ved at spille nutiden sin overlevering i hænde konstitutivt bestemmer den.. Derfor må den historiske bevidsthed, ifølge Gadamer, igennem den hermeneutiske refleksion gøre sig det klart, at dér, hvor det gælder om, "at forstå et historisk fænomen ud fra den historiske distance [...] så ligger vi altid på forhånd under for virkningshistoriens virkninger” (305/ 233). Virkningshistorie refererer altså til den historie, der fuldt ud behersker og bestemmer nutiden. Historie er qua virkningshistorie således ikke noget fortidigt eller som sådan noget afsondret. ${ }^{13}$ Snarere er det "den sandhed, som den hermeneutiske filosofi har fremfort mod den moderne fordrejede historiske og filosofiske bevidsthed, at 'historien' [...] findes i sig selv og således fortsat virker uberegneligt og uforudsigeligt i nutiden"14. Således "afhænger virkningshistoriens magt ikke af, at den anerkendes. Historiens magt over den endelige, menneskelige bevidsthed består netop i", påpeger Gadamer, "også at sætte sig igennem dér, hvor man [som i den historiske objektivismes positivisme] i tiltro til metoden fornægter sin egen historicitet” (306/234).

For Gadamer giver dette anledning til en indtrængende fordring om, "at vi skal blive bevidste om virkningshistorien" (306/234). Hvad der generelt set er meningsfuldt, er dog en nødvendighed for den videnskabelige bevidsthed, der som historisk bevidsthed, sådan som Gadamer kalder det, dermed udvikler sig til en virkningshistorisk bevidsthed. Heller ikke i fuldbyrdelsen af den virkningshistoriske bevidsthed bliver historiens rette sammenhænge og motiver afklaret. "At man nogensinde skulle blive fuldstændig bevidst om virkningshistorien er en lige så hybrid påstand som Hegels krav på absolut viden, den viden hvori historien er blevet fuldstændig selvgennemsigtig, og derfor er ophævet til begrebets standpunkt" (306/234).

Menneskets forhold til dets historie er i højere grad bestemt gennem dets indføjelse (einrücken) i overleveringen. Denne indføjelse betyder således ikke en eksplicit tilslutning til traditionen. Overleveringen, som vi føjer os ind i, går forud for alle forsætlige dispositioner og virker også dér, hvor den endnu ikke er blevet gjort os bevidst som sådan. Virkningshistorien forløber altså ikke lineært eller plant på overfladen. Den er tillige omridsenes og bruddenes, glemslens og de underjordiske forløbs historie. Disse grundforhold formulerer Gadamer i den fundamentale indsigt: "I virkeligheden tilhører historien ikke os, men vi tilhører den" (281/214).

Gadamers historieopfattelse fremstår på sin vis som en pendant til Heideggers udkast til værenshistorien. Den knytter således an til dennes primat om, at historien ikke står til rådighed for for mennesket. Dog adskiller Gadamers virkningshistorie sig fra Heideggers værenshistorie på et væsentligt punkt. 
Heideggers værenshistorie kan læses som en "begyndelsens forfaldshistorie", ${ }^{15}$ der beskriver historien som en værensglemslens historie. Også når Heidegger hævder, at hvad angår epokernes forløb i værenshistorien er der i modsætning til Hegels historieskitse ingen lovmæssighed, ja overhovedet ingen nødvendighed, så forbliver der ifølge Gadamer i dens konstruktion dog "en rest af den logiske tvangskarakter [...] i hvis vold den hegelske konstruktion af tankens verdenshistorie var faldet. Ganske vist var den ikke nogen retrospektiv, teleologisk konstruktion sådan som hos Hegel. Den var en konstruktion ud fra begyndelsen - fra begyndelsen med metafysikkens værenstilskikkelse (Seinsgeschick)."

Gadamers princip om virkningshistorien indeholder til gengæld ingen konstruktion af denne art. Menneskets indføjethed $i$ historien står ikke til rådighed for det selv, men er umiddelbart i erfaringen af at høre ind under en overleveringshændelse, som mennesket nok hermeneutisk kan eksplicitere, men som det aldrig virkelig kan imødegå på afstand. Dets erfaring "udspiller sig mellem den fremmedhed og fortrolighed, som overleveringen har for os." I "dette 'imellem' [...] er hermeneutikkens sande sted" (300/229), og derfor er det umuligt i spørgsmålet om historien at opstille en plantegning over helhedens konstruktion. Ganske vist lader tidsafstanden, sådan som Gadamer viser det, sig udnytte på hermeneutisk produktiv vis, som en slags filter for forstålsen og dømmekraften, eftersom tiden er "fyldt op med traditionernes og sædvanernes kontinuitet, hvori al overlevering viser sig for os" (302/231), men også det kun under endelighedens betingelser, som kun tillader historien at blive erfaret som virkningshistorie, der aldrig fuldt ud vil kunne klarlægges.

Af samme grund er bevidsthed om historien som virkningshistorisk bevidsthed, understreger Gadamer, "først og fremmest bevidsthed om den hermeneutiske situation" (307/234). Dermed bliver bevidstheden som noget virkningshistorisk af historien bundet til de komplekse grundforhold for den menneskelige eksistens' fakticitet, som Heidegger påviste. Tilsvarende karakteriserer Gadamer nu også udtrykkeligt sit begreb om situationen derved, "at man ikke befinder sig uden for den, og derfor heller ikke kan have nogen objektiv viden om den. Man står i en situation, man befinder sig altid allerede i en situation, og det vil aldrig lykkes, at få den fuldt belyst. Dette gælder også for den hermeneutiske situation, dvs. dér hvor vi befinder os over for den overlevering, vi ønsker at forstå. Heller ikke belysningen af denne situation, dvs. den virkningshistoriske refleksion, kan blive endegyldig; men denne ufuldkommenhed skyldes ikke mangel på refleksion, men beror derimod på et væsenstræk ved den historiske væren, som vi er. At være historisk betyder, aldrig at have fuldstændig viden om sig selv. Enhver viden om sig selv træder frem på baggrund af noget historisk forudgivet" (307/234f.). 
I den ovenstående karakteristik af menneskets situerethed høres den absolutte afstandstagen fra den traditionelle subjektivitetsfilosofi, der er et centralt tema i Gadamers filosofiske hermeneutik. ${ }^{17}$ Den bliver i særdeleshed tydelig i første del af "Sandhed og metode", hvor Gadamer udfolder kunstværkets ontologi på grundlag af en teori om spillet. Det hævdes, at hverken et kunstværks eller kunstens sandhed ikke længere afgøres subjektivt af kunstneren eller af recipienten. Gadamer opfatter snarere kunst som en spilhændelse, som besidder et primat i forhold til spilleren (kunstneren/recipienten). Her ligger forbindelsen til "historiebegrebets ontologiske vending", ${ }^{18}$ der lader sig fortøje i Gadamers situationsbegreb. Den enkelte behersker ikke historien, men befinder sig allerede involveret i den og erfarer deri begrænsningerne for sin handleevne. Fremstillet sådan eksponeres der i begrebet om virkningshistorien ontologisk set en ansats, der i stedet for det spontane subjekts primat sætter den enkeltes inddragethed og dermed også afhængighed af de faktisk givne strukturer. ${ }^{19}$

Dette spændingsforhold tydeliggør Gadamer nu ved at fremhæve, at en væsentlig del af situationsbegrebet er horisontbegrebet. Horisonten betegner "det synsfelt, der omfatter og omslutter alt det, der er synligt fra et bestemt punkt" (307/235). I tilslutning til det horisontbegreb, som især er blevet anvendt af Husserl, bliver "loven om den gradvise udvidelse af synsfeltet" altså beskrevet. Gadamer illustrerer det ved hjælp af hverdagssproget: "en person, der mangler horisont, er ikke i stand til at se langt nok, og overvurderer derfor det, der ligger nærmest ved ham. Når man omvendt taler om 'at have horisont' betyder det, at man [...] kan se ud over det [nære]. Den, der har horisont, er i stand til at foretage den rette vurdering med hensyn til [...] alle de ting, der ligger inden for hans horisont. Tilsvarende er oparbejdelsen af den hermeneutiske situation ensbetydende med, at vi opnår den rette horisont for de spørgsmål der opstår i vores møde med overleveringen” (307f./235).

Med hensyn til den historiske bevidsthed afværger Gadamer den misforståelse, som holder fortid og nutid for at være partialhorsionter, der er lukkede om sig selv, og at det skulle være historikerens opgave at se bort fra sin egen situerethed som led i indfølingen i fortiden. Dette er lige så utilstrækkeligt som at underkasste fortiden sine egne nutidige målestokke. "Når vores historiske bevidsthed sætter sig ind i historiske horisonter, er det ikke ensbetydende med, at vi overflyttes til fremmede verdener, der ikke har nogen som helst forbindelse med vores egen; derimod danner de tilsammen den ene, store horisont, der er bevægelig indefra og som, idet den går ud over det nutidiges grænser, omfatter vores selvbevidstheds historiske dybder. I virkeligheden er det altså én eneste horisont, der omfatter alt, hvad den historiske bevidsthed rummer i sig" (309/237). 
Denne enhedshorisont er i overensstemmelse med Gadamers strukturelle udfoldelse af historien som virkningshistorie imidlertid ikke igen lukket om sig selv. For nok betegner situationen den bundethed til stedet, som mennesket er underlagt i og med dets endelighed, men denne er dog i sig selv et dynamisk forhold. Deraf følger, at hverken fortidshorisonten eller nutidshorisonten - eller den enhedshorisont, der omfatter dem begge - er noget i sig selv. Snarere er horisonten noget "som vi vandrer ind i og som vandrer med os" (309/236), og som herindenfor lader fænomener dukke op og forsvinde. Deri er det desuden begrundet, at historiske fremtrædelser bliver forældede, men også at de vender tilbage $i$ en renæssance. Modens historie byder i den forbindelse på tilstrækkelige eksempler, ja den synes sågar at være konstitueret som en refleks af denne "bevægelige horisont, som det menneskelige liv altid lever ud fra" (310/237).

Det horisontbegreb, som Gadamer således har vundet, knytter an til hans undersøgelser af forståelsens fordomsagtighed ${ }^{20}$, for så vidt at horisontens stadige selvdannelse $i$ nutiden besidder sin drivkræft deri, at vi i overensstemmelse med forståelsens hermeneutisk fritlagte strukturer til stadighed må afprøve og kontrollere de forud-opfattelser, der bestemmer os. Til denne oparbejdelse af forudforståelsen hører imidlertid, at den faktisk selv er situeret i overleveringshændelsen. "Nutidshorisonten kan altså slet ikke dannes uden fortiden" (311/238). Denne sammentræfskarakter af nutid og fortid som en horisontmæssig hændelsessammenhæng udtrykker Gadamer i begrebet horisontsammensmeltning.

Hvad der menes med det hyppigt misforståede og kritiserede begreb om sammensmeltning som fænomenal forekomst, viser han med et blik på fænomenet tradition: "En sådan sammensmeltningskraft [...] finder hele tiden sted $i$ en tradition. For her vokser gammelt og nyt bestandigt sammen igen til en levende betydning, uden at det ene klart udhæves fra det andet" (311/238). Trods denne ukomplicerede begrundelse for anvendelsen af begrebet kommer Gadamer derpå imidlertid med en indvending mod sig selv, idet han spørger, hvorfor man i stedet for horisontsammensmeltning ikke bare taler om "dannelsen af én horisont, som forskyder sin grænse bagud i overleveringens dyb" (311/238). En sådan betegnelse - således kunne man opfatte hans indvending mod sig selv - forhindrer den misforståelse, i sidste ende blot at betragte sammensmeltningen som en syntese af forudgående, selvberoende partialhorisonter.

I modsætning til denne opfattelse af sammensmeltningen, der følger en naturlig sprogbrug, betoner Gadamer, at den metodologiske term "horisontsammensmeltning" fra første færd henviser til den forståelse, der allerede reflekterer sig selv som hermeneutisk bevidsthed og stillet over for den vi- 
denskabelige opgave ser, at med hensyn til det spændingsforhold, der erfares i overleveringens møde med nutiden, må man søge "bevidst at udfolde dette spændingsforhold og ikke at tilsløre det ved naivt at udligne det. Derfor er udkastelsen af en historisk horisont, der hæver sig ud fra nutidshorisonten, nødvendigvis en del af den hermeneutiske indstilling" (311/238). Dette udkast er dog selv kun "en fase i forstålsens fuldbyrdelse; den bliver ikke [som i den historiske objektivisme] til en størknet, fortidig bevidstheds selvfremmedgørelse, men indhentes af nutidens egen forståelseshorisont" (312/239). Det er imidlertid forløbet i horisontsammensmeltningen, der, idet "den udkaster den historiske horisont, fører til dens ophævelse" (312/239), og det fuldt ud $i$ betydningen af en appliceret effekt. For den hermeneutiske forståelse kommer det ifølge Gadamer især an på "den kontrollerede fuldbyrdelse af denne sammensmeltning" (312/239), der fuldbyrdes som effekt af den virkningshistoriske bevidsthed.

Den virkningshistoriske bevidstheds struktur bestemmer Gadamer, idet han så at sige modstandsdygtigt knytter an til Hegels dialektiske erfaringsbegreb som hermeneutisk erfaring. I opposition til den aristoteliske tradition, der primært var interesseret $i$ at få udarbejdet erfaringens almene strukturer, flyttede Hegel nu selve erfaringsprocessen i fokus. Dermed kom historiciteten til sin ret, hvorfor Hegel også er "et vigtigt vidnesbyrd" (359/276) for Gadamer. Med fuldbyrdelsen af erfaringen bliver det erfarende subjekts situation imidlertid også et tema, og her viser det sig, at for subjektets vedkommende er denne proces i det væsentligste bestemt gennem negation.

Allerede den sædvanlige måde, hvorpå man taler om, at nogen gør sig en erfaring, viser som oftest, at en intenderet meningsforventning er blevet skuffet, men at man ud over denne skuffelse har opnået ny viden. "Erfaringens negativitet har altså en ejendommelig, produktiv betydning" (359/276). I tilslutning til Hegel betegner Gadamer den type erfaring som dialektisk. For Hegel er det nemlig bestemmende, at den erfarende bevidsthed i fuldbyrdelsen af en erfaring samtidig vender sig mod sig selv som erfarende bevidsthed og således skaber en horisont for mulige nye erfaringer. ${ }^{21}$

Så langt følger Gadamer Hegel i dennes beskrivelse af den dialektiske erfarings struktur, ligesom han formelt tilslutter sig, at, som Hegel formulerer det, "for at antage og holde et indhold for sandt må mennesket selv være til stede, eller mere bestemt, at han finder, at dette indhold stemmer overens med og er forenet med visheden om sig selv". 22 For Gadamer fuldbyrder denne forening sig som selverkendelsens og selvbestemmelsens proces, altså som identitet $i$ erfaringen af det fremmede, den anden, differensen. Dermed kommer Gadamer imidlertid i opposition til Hegel, hos hvem bevidsthedens erfaringsproces munder ud i en viden om sig selv, hvori intet anderledes står over for den. 
Tilsvarende gælder det for Hegel, "at erfaringen fuldendes i 'videnskaben', visheden om sig selv i viden" (361/277), der som absolut viden således har overvundet al erfaring, og det vil sige har opnået fuldkommen identitet mellem bevidsthed og genstand.

Dermed bliver målestokken for viden hos Hegel gennemtrængt af noget, hvori erfaringen selv allerede apriori er transcenderet. Netop dette strider imidlertid imod fakticitetens fænomenonale udfald, der blev vundet gennem den hermeneutiske refleksion, og dermed også mod forståelsens historicitet. Gadamer betoner derfor udtrykkeligt: "erfaringens sandhed indeholder altid en relation til nye erfaringer. Derfor er en såkaldt person ikke blot blevet erfaren gennem erfaringer, men er også åben for nye erfaringer. [...] Erfaringens dialektik [i fuldbyrdelsen af de tre trin forventning, skuffelse, ny holdning] fuldendes ikke i en endegyldig viden, men i den åbenhed for erfaring, der selv gøres mulig af erfaringen" (361/277).

Denne åbenhed forbinder sig som erfaringens andet væsensmoment med den allerede omtalte negation, som jo bidrager til at konstituere forventningen i forløbet med skuffelsen af forventningen. I den forbindelse er det vigtigt at lægge mærke til, at for den arbejdende erfaring er ingen stedfortræder mulig. For kun gennem den erfaring, som den erfarne person har gjort sig på negationens vej, vinder han en større indsigt. Indsigt er derfor foruden negation og åbenhed det tredje moment $\mathrm{i}$ erfaringens væsen.

Indsigt, hvor meget den nu end relaterer sig til noget tingsligt, indeholder "altid et moment af selverkendelse" (362/278). Dermed knytter dette moment accentueret over Heideggers eksistentiale struktur an til, at al forståelse altid er en forståelse af sig selv. Og deri fremtræder anvendelsen, applikationen som forståelsens strukturmoment. Som denne selverkendelse er indsigten ifølge Gadamer i det væsentligste indsigt i "grænserne for det at være menneske" (363/278). Derfor er en erfaring i sit væsen "erfaring af den menneskelige endelighed" (363/278). Gadamer påpeger, at "gennem erfaring lærer man at anerkende det virkelige" (363/279). Afgørende for dette er, at anerkendelsen af det, der er, betyder "indsigt $i$, at det er begrænset, hvor meget fremtiden er åben for vores forventninger og planer (363/279), og dét vel at mærke som endelig mulighed for endelige mennesker. "Den egentlige erfaring er den, hvor mennesket bliver bevidst om sin endelighed" (363/279), og dermed er den "erfaring af ens egen historicitet" (363/279). I den menneskelige tilværens endelighed "finder den planlæggende fornufts selvbevidsthed og dens ønske om at-kunne-gøre sine grænser" (363/279). Ganske træffende har Grondin derfor kendetegnet Gadamers hermeneutik som en "endelighedshermeneutik". ${ }^{23}$

Der knytter sig imidlertid ingen resignation til indsigten i endeligheden, men 
derimod en "refleksionsgevinst". 24 De almene væsenstræk for menneskelig erfaring, der påvises derved, kan nu fremdrages som strukturmomenter i den hermeneutiske erfaring, der jo forholder sig refleksivt til overleveringen. ${ }^{25}$ Det afgørende moment i bestemmelsen af den hermeneutiske erfaring bliver dermed dens åbenhed for overleveringen, som Gadamer fremhæver som den "højeste form for hermeneutisk erfaring" (367/281). I denne åbenhed ligger, at overleveringen gennem sit krav får lov til at gælde som en sådan, der har noget at sige mig. Gadamer tolker overleveringens forhold til jeget $i$ analogi til en samtale mellem "jeg" og "du", der kun er et samtaleforhold, hvis jeg anerkender dette "du" $i$ dets anderledeshed og lader det sige mig noget.

\section{III.}

Baggrunden for denne sprogmodel er, at det er ud fra sagen selv, og altså ikke ved jegets sætten, at målestokken for og graden af forståelse udformes. "Hvad der fordres er blot åbenhed for den andens eller tekstens mening" (273/208), hedder det hos Gadamer, og "hvis man ønsker at forstå en tekst er man [...] indstillet på at lade den sige en noget" (273/209). Tekstbegrebet tilskrives altså en så omfattende betydning af Gadamer, at overleveringen i sin helhed fremstår som en slags tekst, hvorfor det da også er i Gadamers overvejelser over tekstens struktur, at de mest lærerige passager for en videre bestemmelse af vort forhold til overleveringen kan findes.

Den dialoglignende situation, der lader sig begribe som forholdet mellem den overlevering, der formidles gennem teksterne og dermed altså gennem sproget, og læseren samt forfatteren, og på denne måde bliver det ligeledes antydet af Gadamer, ${ }^{26}$ bør dog ikke tillægges al for stor vægt, hvad angår det dialogiske. For det væsentlige i dette forhold er i sidste ende, at i "forstålsen af overleveringen opfattes den overleverede tekst ikke som en anden persons livsudtryk, men som et meningsindhold, der er løsrevet fra både din og min mening" (364/279). Det betyder dog tillige, at en rekonstruktion af forfatterens budskab i en tekst, der rækker ud over teksten, hverken er meningsfuld eller mulig ifølge Gadamer. Ud fra denne synsvinkel nærmer Gadamer sig dermed de teoretiske positioner, der propaganderer for forfatterens forsvinden i eller bag teksten, ${ }^{27}$ for så vidt at også den løsrivelse, Gadamer omtaler, sprænger det umiddelbare0 dialogiske samtalemønster, ja strengt taget bringer det til ophør - om end det skal indrømmes, at Gadamers formulering er en kende uskarp, eftersom han gang på gang bestemmer forholdet til teksten som en dialektik eller logik mellem spørgsmål og svar og altså således både som en samtalemodel og gennem en samtalemodel. Trods lejlighedsvise svagheder i formuleringen må det for Gadamers vedkommende overordnet fastholdes, at 
selv i de tilfælde, hvor teksten stiller spørgsmålet, bliver hverken teksten eller den overlevering, der formidles i den, hypostatiseret til et subjekt sui generis. Snarere betyder "det spørgsmål, teksten stiller os, at [...] forståelsen af det altid indebærer, at nutiden bliver historisk formidlet med overleveringen" (379/292), og at det på denne vis kun får status af spørgsmål ud fra den virkningsrelation, som teksten udfolder hos læseren.

I den virkningshistoriske bevidsthed pålxgges hermeneutikken følgelig den opgave, at belyse og afklare forståelsens historiske situerethed i dens fuldbyrdelsesbetingelser, samt at reflektere den deri indbefattede endelighed for forståelseskravet. Man optræder nu engang aldrig nogensinde selv som et ubeskrevet blad, men snarere som et lakmuspapir, der i mødet med den konkrete tekst erfarer sin reaktion på den og følgelig også på sig selv, idet man rykker ind i overleveringshændelsen, altså at man fletter sig ind i det net, der er knyttet sammen i teksten, og således aktualiserer dets virkningspotentiale $\mathrm{i}$ ens læsnings grænseoverflade og derigennem modificerer læsningen - og i øvrigt også sig selv. ${ }^{28}$

Med hensyn til dets aktualisering i den virkningshistoriske bevidsthed bliver dette virkningshistoriske forhold særdeles tydeligt, såfremt man indlader sig på betragtninger over iscenesættelse af teater og opera igennem historien, hvorfor dette til sidst på eksemplarisk vis vil blive tydeliggjort ved hjælp af forskydninger i karakteren af opførelsen af Shakespeares "The Merchant of Venice". Dette eksempel er velegnet dertil, fordi i opgaven med den sceniske aktualisering af teksten vil det nærværsontologiske såvel som æstetisk vigtige spørgsmål om den hermeneutisk-historiske situation som erfaringsrum for iscenesættelsen uundgåeligt dukke op hos alle deltagerne. Med hensyn til købmanden kunne man i konstruktionen af eksemplet så for det første lede tankerne hen på Fritz Kortners berømte fortolkning af Shylock, der som baggrundsstemme - og tillige med stykkets rum som subtil sufflør, og som indvævet $\mathrm{i}$ tilskuerens bevidsthed $-\mathrm{i}$ bogstaveligste forstand indføjer den historiske erfaring af Holocaust i rolleteksten som metekel såvel som palimpsest. Shylocks klage efter retfærdighed bliver i sin apori til en tragisk konflikt om den skyldløse skyldige eller skyldige skyldløse, der i sin person (ud)holder sit folks skæbne. Dermed forvandler komedien sig til tragedie, og Kortners Shylock forfremmes til Lears åndelige slægtning. Peter Zadeks wiener iscenesættelse af "The Merchant of Venice" i 1992 individualiserer derimod atter figurerne, lader dem agere i en nærmest areligiøs verden styret af penge, hvormed den i forhold til Otto Schenks iscenesættelse på sin vis skærper den religiøse betydningsdimension. Ud fra sin egen virkelighedsiagttagelse af 80'ernes samfundsmæssige realitet åbner Zadek dermed stykkets rum for muligheden af at vise de handlende personer som parthavere i et økonomisk styret samfund, og 
hvori han som refleks på "gender history" diskursen om mændenes afmægtige magt tillige fremhæver den kvindelige list som lignelse i forholdet mellem kønnene. Således genvinder stykket sin komedianske side, der har bestemt dets reception helt frem til Max Reinhardt og således placeret "The Merchant of Venice" i naboskabet til "As You Like It". I tekstens virkningsstrøm negerer Zadeks Shylock dog på ingen måde Kortners udlægning, han ophæver den ikke, men besvarer den, idet han aflytter teksten for muligheder for dens aktualisering, der finder en egen autencitet i den virkningshistoriske bevidsthed om sin egen situering som dennes realisering, og som også jødernes historie $\mathrm{i}$ det 20. århundrede er en fast og umistelig del af.

Derfor bliver spørgsmålet om, hvordan "Købmanden fra Venedig" kan iscenesættes i dag, her bl.a. besvaret med, at det tidstypiske, elisabethianske, antisemitiske ressentiment, der så absolut klinger med igennem hele stykket, ikke længere bliver gjort til konstituent for bedømmelsen af handlingen, der tidligere nemlig stræbte efter at inddrage tilskueren som medsammensvoren $\mathrm{i}$ et stiltiende samarbejde om samfundsmæssige fordomme dermed. Den virkningshistoriske bevidsthed svarer således også der, hvor komedien nu atter dominerer i skuespillets undertone, stadig i ét med ekkoet fra ofrenes mange stemmer. Således forbliver historie som virkningshistorie her som i det hele taget det erfaringsrum, man ikke kan gå bagom, og som den virkningshistoriske bevidsthed gennem sine refleksive anstrengelse ganske vist kan aktualisere og åbne, men refleksionen formår dog aldrig helt at gennemtrænge det. Som konstitutiv betingelse for al forståelse, herunder især for den historiske, udformer historien altså også forståelsens grænser i sig. At erkende grænser betyder trods alt altid at inddrage dem i spillet om deres overskridelse. Således henviser erfaring og historie skiftevis til hinanden i en uophævelig sammenhæng, idet de først konstituerer hinanden i denne vekselvirkning.

\section{Noter}

1 E. Angehrn: Geschichtsphilosophie. Stuttgart/Berlin/Köln, 1991, s. 183. Jf. i øvrigt idem.: Geschichte und Identität. Berlin/New York, 1985.

2 E. Angehrn: Geschichtsphilosophie, s. 183.

${ }^{3}$ G. Picht: Geschichte und Gegenwart. Stuttgart, 1993, s. 6.

${ }^{4}$ Idem, s. 5.

5 Ud fra dette perspektiv kunne man med en pointeret spidsformulering hævde, at holdbarshedsdatoen, teoretisk set, for den marxistiske historiemodel (som den måske sidste historiefilosofisk motiverede "store (meta-)fortælling blev overskredet meget tidligere end, at den mistede sin historiske betydning som ideologi. 
${ }^{6}$ W. Dilthey: Der Aufbau der geschichtlichen Welt in den Geisteswissenschaften. Red. M. Riedel. Frankfurt/M, 1970, s. 98.

7 W. Dilthey: Traum. In: Zur Weltanschauungslehre. Gesammelte Schriften, vol. VIII. Leipzig/Berlin, 1931, s. 224.

${ }^{8}$ Jf. i den forbindelse forfatterens: Positivismus als Metaphysik. Voraussetzungen und Grundstrukturen von Diltheys Grundlegung der Geisteswissenschaften. Freiburg/ München, 1988.

${ }^{9}$ H.-G. Gadamer: Wahrheit und Methode. Gesammelte Werke, vol. 1. Tübingen, 1986, s. 348/267 [i det følgende vil alle henvisninger til „Wahrheit og Methode“ blive anført i teksten i parentes, hvori der vil blive henvist til den her anførte tyske oversættelse samt - dernæst - til den danske oversættelse ("Sandhed og metode : grundtræk af en filosofisk hermeneutik" (2004)) ved Arne Jørgensen. Den danske oversættelse er i øvrigt benyttet her].

${ }^{10}$ D. Teichert: Erfahrung, Erinnerung, Erkenntnis. Stuttgart, 1991, s. 110.

${ }^{11}$ J. Grondin: Einführung in die philosophische Hermeneutik. Darmstadt, 1991, s. 147.

12 I praksis bør det derfor heller ikke blive forvekslet med den litteraturvidenskabelige underdisciplin ved navn "receptionshistorie", som retter sig mod den konkrete udforskning af det enkelte litterære værks virkning.

13 Den historiske objektivisme troede, at den ved hjælp af sin positivistiske metode standspunktsneutralt og i den forstand objektivt kunne behandle historiske begivenheder analogt med naturfænomener.

14 M. Riedel: Jenseits des Bewusstseins. In: Verstehen und Geschehen. Symposium aus Anlass des 90. Geburtstag von H.-G. Gadamer. Jahresgabe der Martin-HeideggerGesellschaft, 1990, s. 27. For forholdet mellem værens- og virkningshistorie, se. M. Riedel: Hören auf die Sprache. Die akromatische Dimension der Hermeneutik. Frankfurt/M., s. 355-382.

${ }^{15}$ M. Riedel: Jenseits des Bewusstseins, s. 36.

${ }^{16}$ Gadamer: Die Geschichte der Philosophie. In: Gesammelte Werke, vol. 3, Tübingen, 1987, s. 300.

17 Jf. D. Teichert: Erfahrung, Erinnerung, Erkenntnis. Stuttgart, 1991, s. 112. For Gadamers kunstteori, idem.: s. 32-52.

18 Idem., s. 112.

${ }^{19}$ Her vil man helt sikkert kunne finde berøringspunkter med Michel Foucault, der ville være egnede som udgangspunkt for en frugtbar samtale mellem hermeneutikken og diskursanalysen.

${ }^{20}$ Jf. Wahrheit und Methode, s. 270-295.

21 Jf: Hegel: Phänomenologie des Geistes, Einleitung. In. Werke, vol. 3. Frankfurt/M., 1976, s. $78 \mathrm{ff}$.

${ }^{22}$ Hegel: Enzyklopädie der philosophischen Wissenschaft. In: Werke, vol. 8, Frankfurt/M. 1973, s. 49.

23 J. Grondin: Philosophische Hermeneutik, s. 148. 
${ }^{24}$ Idem.

25 I den forbindelse er det, som Teichert påpeger, vigtigt at være opmærksom på, "at Gadamer forbliver inden for rammerne af sine generelle overvejelser om erfaringsbegrebet, og at han netop ikke definerer den hermeneutiske erfaring [i modsætning til den situativt relaterede processuelle erfaringskarakter] som en privilegeret, metodisk disciplineret, videnskabelig forskningsproces (D. Teichert: Erfahrung, Erinnerung, Erkenntnis. Stuttgart, 1991, s. 121)..

26 "Men overlevering er ikke blot en hændelse, som man lærer at erkende og beherske gennem erfaring, men er derimod sprog, dvs. den taler til os ligesom et du. Et du er ikke nogen genstand, men forholder sig til én" (363f./279).

27 Blandt disse kunne man f.eks. nævne den sene Merleau-Ponty, Derrida, Levinas eller Foucault. Jf. i den forbindelse B. Waldenfels: Antwortregister. Frankfurt/M, 1994, s. 122146.

28 jf. Hans-Helmuth Gander: Selbstverständnis und Lebenswelt. Gundzüge einer phänomenologischen Hermeneutik im Ausgang von Husserl und Heidegger, Frankfurt/M 2001, særlig $\iint 3-13$. 